Review

\title{
Barriers and Levers to Developing Wheat-Pea Intercropping in Europe: A Review
}

\author{
Fateh Mamine * and M'hand Farès \\ UMR Selmet, INRAE-ACT, 2 place Pierre Viala, 34060 Montpellier, France; mehand.fares@inrae.fr \\ * Correspondence: fateh.mamine@inrae.fr
}

Received: 30 July 2020; Accepted: 22 August 2020; Published: 26 August 2020

\begin{abstract}
Beyond the ecosystem benefits of diversification through wheat-pea intercropping, this review analyzes the barriers and levers to its adoption and diffusion. The present review shows that structuring the value chain around the products of this innovative cropping system faces a set of technical (i.e., varietal selection, phytosanitary issue control, crop management sequence, collection management, and storage), economic (i.e., cost, price, market opportunities, and contracting), and public policy (i.e., subsidies for ecosystem services provided by intercropping) obstacles that contribute to its slow adoption and dissemination in Europe. However, the value chain resulting from the wheat-pea intercropping system has levers to be exploited at all levels, particularly in terms of its competitive advantages, ecosystem benefits, and superior product quality. The results of this review help to identify priorities that actors of the value chain can address to better focus their efforts on significant problems and solutions that can accelerate the adoption and dissemination of this agroecological system.
\end{abstract}

Keywords: intercropping; wheat-pea; barriers; levers; agroecology; Europe

\section{Introduction}

The development of agriculture in developed countries since the end of the Second World War was driven by the use of chemical inputs and genetic selection. The use of chemical inputs has made it possible to shorten crop cycles and reduce rotation times, with the possibility of switching to monoculture in some cases. Even though they dramatically increased the agricultural yields, such practices have also led to a decline in species diversity. Coupled with varietal selection within species, these practices have greatly reduced crop biodiversity and its associated natural biodiversity, which is also declining at the same rate [1]. Diversification by intercropping facilitates the partial restoration of biodiversity by introducing new species and lengthening the crop rotation cycle.

The cereal-legume association is of great interest in terms of increasing biodiversity in the field [2]. This association represents an agroecological practice based on the biodiversity of a multispecies system that reintroduces synergistic effects between plants and other regulatory mechanisms conducive to the resilience of ecological sustainability [3,4].

Cereal-legume intercropping using crops such as wheat and pea represents one of these diversification systems. It promotes a certain ecological intensification through which one can ensure a quantitative dry matter yield equivalent to that produced by the same two pure crops while increasing protein yield and reducing nitrogen fertilization [5]. This system aims to establish two crops that are complementary in nutritional and morphological terms. The symbiotic relationship between the legume (pea) and the bacteria housed in the nodes of its root system enables the plant to fix atmospheric nitrogen, thereby allowing it to meet its nitrogen nutrient requirements. Due to the high competitiveness of cereals in terms of nitrogen uptake and the sharing of soil with legumes, wheat can benefit from the natural nitrogen supply released by pea roots $[2,6,7]$. For farmers, interest in this 
system is twofold: (1) reducing nitrogen inputs and production costs while (2) ensuring production with less pollution, since the mineral nitrogen typically used in conventional agriculture is very leachable. The competitiveness of cereal crops in terms of nitrogen absorption allows them to capture residual mineral nitrogen from previous crops, whereas the symbiotic fixation of atmospheric nitrogen by legumes provides a cleaner resource for its needs while helping to meet the nutrient requirements of its partner [8-11]. Some studies [12,13] have shown that the natural $\mathrm{N}$ input associated with mineral $\mathrm{N}$ supply can be an important technical lever to control the yield of the cereal-legume intercropping. Finally, the residual organic matter of this system, which is proportionally richer in nitrogen compared to monocropping, can help to replenish the soil's mineral reserves and, thus, preserve its natural fertility $[10,11,14,15]$.

The best complementarity observed between wheat and peas is that of nitrogen, which is achieved through the optimal use of soil mineral nitrogen (by wheat) and fixed nitrogen (by pea) in their different growth cycles, thereby leaving fewer resources for weed development. The cereal (wheat), which is already more competitive in its use of mineral nitrogen, impulses the legume (pea) to fix more atmospheric nitrogen by symbiosis to meet its needs, which hinders the development of weeds due to the lack of nitrogen resources [16-18]. Another factor that can explain the reduction of weeds and infectious diseases in intercropping is allelopathy, which is the direct or indirect biochemical interaction exerted by associated plants to inhibit weeds or pathogens [19-22].

Thus, this intercropping meets not only the need to reduce chemical inputs (fertilizers and phytosanitary products) and their associated production costs but also the need to secure yields to address interannual variability [23-25]. The better quality of wheat produced in intercropping with pea can also have economic benefits for farmers by increasing the protein rate. In organic farming, the production of common wheat is more valuable on the market due to its high protein content. However, nitrogen input is the main factor limiting this highly sought-after qualitative performance [26]. To remedy the lack of mineral fertilization in organic farming, the intercropping of common wheat with legumes such as peas is an interesting technical and economic alternative [27]. However, this farming practice must be considered in its context to highlight the levers that can be exploited and the barriers that must be lifted for its successful implementation.

The analysis presented in this paper is based on a literature review of the current context of diversified cultivation through wheat-pea intercropping in Europe. This synthesis is part of the ongoing work (June 2017 to May 2022) of the European project DiverIMPACTS (Diversification through rotation, Intercropping, Multiple cropping, Promoted with Actors and value chains towards Sustainability), which aims to explore the full potential of crop system diversification to improve productivity, the provision of ecosystem services, and sustainable and resource-efficient value chains in Europe. This process involves assessing the performance of crop diversification to provide stakeholders with the tools and innovations required to remove existing barriers and ensure the effective use of crop diversification benefits at the farm, value chain, and territorial levels while making recommendations to policymakers to facilitate the coordination of all relevant actors within the value chain.

Beyond highlighting the benefits of this agroecological cropping system, the objective of this paper is to analyze the barriers and levers to its adoption and diffusion. Therefore, this review aims to identify priorities to be addressed by research and development (R\&D) and wheat-pea value chain actors to better focus their efforts on significant issues and solutions to accelerate the adoption and dissemination of this innovative system. Following this introduction, the first part of this paper presents an analysis of the technical, economic, and public policy obstacles to the adoption and dissemination of wheat-pea intercropping in its current state of practice in Europe. The second part of this paper provides an analysis of the possible levers to endorsing the dynamics of adopting and disseminating this agroecological practice at several levels of the value chain (from production to consumption) through public, private, and market incentive mechanisms. This discussion is followed by an overview of the conclusions of this review. 


\section{Barriers to Developing the Wheat-Pea Intercropping Value Chain}

\subsection{Lack of Specific Input Suppliers}

As with most innovative products on the market, specific inputs adapted to wheat-pea intercropping (e.g., seeds, fertilizers, and plant protection products) are protected by marketing licenses. Moreover, the R\&D cost of these patents is reflected in the price negotiated by intermediaries (input suppliers), which may also represent a barrier to their marketing. Moreover, the multiplication of "rights-holders" (i.e., research laboratories, seed companies, and agricultural supply companies) considerably increases the transaction costs required to market innovative inputs adapted to new cropping systems. These two factors cause a "tragedy of enclosures", reflecting a situation of self-locking where excessively strong property rights on innovative inputs lead to their under-marketing [28,29]. Notably, the availability of input suppliers has often been an important lever for the adoption and diffusion of new technologies [30-33].

\subsection{Lack of Technical References and Specific Advice for Production}

The design of a technical guide remains difficult to establish given the variability and complexity of the agroclimatic parameters specific to each agrosystem. Varietal choice (see below) can affect the sowing and harvesting dates and optimal timing for treatment or fertilization, and, thus, yield quantity and quality. Various studies performed in this area have recommended certain practices without defining technical references. Such works also involved experiments that aimed to define the dosage at sowing (e.g., wheat/pea ratio, spacing), fertilization, and treatment (where applicable) [23,34-45]. Despite their convergence on certain issues, these studies do not provide a universal technical guide that farmers can use for wheat-pea intercropping. The current state of technical knowledge may be a source of failure for wheat-pea intercropping in the short and medium-term, which can result in its long-term abandonment by farmers.

The lack of proven technical knowledge to clarify and advise economic operators in the value chain adds to the lack of technical reference systems at the farm level. Currently, neither the technical advisors of professional agricultural organizations nor those of cooperatives can provide detailed technical advice on the practice of wheat-pea intercropping [46]. Even computer-based tools used to simulate and assess the agronomic and environmental performance of cropping systems are not parameterized to support the activities of these actors [47]. While individualized technical advice is conceivable, the associated costs and funding sources remain largely unknown. As such, the cost of technical learning and its coverage for implementing innovative agricultural practices remain obstacles to its adoption [48]. Learning new knowledge related to the practice of wheat-pea intercropping remains hindered by the conventional training and agricultural advisory system, which is limited to the dissemination of standard knowledge on the practice of conventional crops [49]. Compared to conventional crops, wheat-pea intercropping does not benefit from the learning effect that leads to the accumulation of knowledge and increasing yields over time. The few experiments conducted by farmers that support the credibility and technical and economic viability of this practice do not make it possible to consolidate the production and dissemination of knowledge in this field.

\subsection{Difficulty in Establishing Varietal Choices}

The scientific literature dealing with crop diversification highlights some technical constraints related to the genetic progress of these crops [4,50,51]. This is particularly true for cereal-legume intercropping, where selecting species should define a balanced proportion of joint satisfactory production of two products [23,52-54]. In the case of wheat-pea intercropping, the difficulty involves selecting varieties for two different crops that have a concordant technical production itinerary in terms of crop calendar (i.e., sowing and harvesting dates) and morphological compatibility. This would allow wheat with the lowest susceptibility to lodging being used as a stake for the peas due to its creeping characteristic. While research on this issue is progressing, it remains compartmentalized and more 
oriented toward varietal adaptation to local soil and climate conditions (soil type, rainfall, possibility of irrigation, etc.) $[18,55,56]$. The lack of progress in this field is due to the self-reinforcement effect that characterizes the conventional agricultural research system, where all research and development resources are oriented toward the production of varieties and species adapted to the conventional seed market. Notably, this sector is marked by the phenomenon of increasing returns. Therefore, its players have more interest in working on known and well-worked species or varieties than on new species or varieties where the expected return on investment is not guaranteed. In addition, varietal selection is experiencing strong upstream market restriction due to property rights, which result in farmers' dependence on seed companies and the under-utilization of genetic progress $[28,29,57]$. One might believe that wheat-being a major field crop—would have advantages in this area; however, the problem stems from varietal selection. Based on research work on this intercropping system using the same varieties used in pure crops, the latter do not behave in the same way [16]. Thus, the interaction between these two species (wheat and pea) is a major obstacle to selection [58].

\subsection{Insufficient Control of Sanitary Issues}

Although wheat-pea intercropping can be useful in reducing pests, weeds, and diseases, the health problems related to this practice are not completely solved. Weed control remains a necessity under certain agroclimatic conditions $[34,37,38,59]$. If mechanical weed control is not possible for the intercrop in the same row, spraying is necessary. In addition, certain pests such as pigeons, aphids, pea Sitones, and Mycosphaerella pinodes must still be controlled [20,55,60-65]. This must be done in addition to disease treatments that may be necessary for both species despite the beneficial effect that intercropping has on pathogen dynamics [66]. Although farmers have enough technical means to treat pure crops, their challenge in intercropping lies in choosing specific treatments without negatively affecting one of the associated species. Farmers must not only invest in new machinery adapted to the treatment of wheat-pea intercropping, but also seek new knowledge on alternatives to the crop protection products typically used in pure crops. Notably, peas in pure crops suffer from a lack of phytosanitary solutions for certain soil-borne diseases such as the fungus Aphanomyces euteiches, which causes significant yield losses and can be a source of great uncertainty for farmers. This disease, which affects pea roots and for which neither a phytosanitary product nor a resistant variety exists, can remain in the soil for long periods (at least five years) and thus hinder the extension of wheat-pea intercropping. Against all expectations, wheat-pea intercropping-which has been promoted for its positive effects on the management of bio-aggressors - can come with the risk of bio-aggressor proliferation $[67,68]$ and complications in implementing the usual sanitary protocols. In addition, the extension of rotation by introducing the wheat-pea intercropping may make weed management more difficult, which further complicates the implementation of sanitary protocols in diversified farms. The configuration of long or short rotations for wheat-pea intercropping will inevitably affect the sanitary management of plots. Long rotations of over six years, which are recommended to avoid pea root rot disease (Aphanomyces euteiches), are not favorable for enhancing the beneficial effect of the intercropping on the following crop. Moreover, a long rotation is synonymous with a lower arable land area [68]. For farmers, wheat-pea intercropping carries a double risk due to the considerable increase in initial investment and uncertain yield, which heavily depends on sanitary crop management. If the introduction of intercropping in a short or long rotation can be difficult, its position in the rotation does not matter. Nevertheless, it is generally advisable to place the intercropping behind a straw cereal or a root crop or even as a third straw. A previous meadow may also be suitable, but the nitrogen potential will not be valorized as with a pure cereal. Some people advise placing them at the end of the rotation, before a meadow or alfalfa, mainly for reasons of controlling soil parasites. Succession of associations is possible if the alternation of winter and spring associations is respected. 


\subsection{Unstable or Inadequate Yield}

Farmers' lack of control over the technical and economic aspects of production leads to unpredictable yields, which are a source of uncertainty in terms of the economic viability of intercropping. The results of full-scale field trials reported by the Belgian Professional Association "ASBL Fourrage Mieux" (Better Fodder) and in the Hungarian context [69] suggest that the yields of this intercropping system are insufficient when compared to monocropping. However, some authors [2,70] report less yield instability and even productivity gains in the context of organic farming in France. In this sense, an increase of wheat yield from $15 \%$ to $21 \%$ was also found under intercropping with grain legumes such as peas in the context of Lithuanian organic agriculture [71]; however, this yield remains unstable following legume species. Yield is influenced by several pedoclimatic factors in addition to agronomic practice parameters (i.e., resource availability, the relative frequency of species, and the density of intercrop components) $[23,44,45,63,72-75]$. Yield instability is a direct result of the lack of treatment and fertilization parameter control, which can lead to variability in wheat-pea mixture composition at harvest [43]. In any case, the uncertainty and comparative cost-benefit weighing of wheat-pea intercropping compared to field crops (whose technical-economic itinerary-and thus yields-are well controlled) support the abandonment of intercropping [76]. Moreover, variability in the quantity and quality of intercropping products does not encourage economic operators in this value chain to commit to long-term contract relationships $[22,26]$.

\subsection{Higher Production Cost}

Despite the savings on chemical inputs for fertilization and phytosanitary treatment noted by several studies $[8,12,13,41,60]$, the production cost of wheat-pea intercropping remains high $[2,77-79]$ due to the increased costs related to the purchase of specific inputs (e.g., seeds, fertilizers, and phytosanitary products) as well as sowing, collection, and sorting operations after harvest. In terms of sorting operations, the farmer must spend or compensate the equivalent of $15 €$ per ton (estimates made in France), which includes both separating pure products from the mixture and the loss of peas that were not separated from wheat. This cost remains partial since it does not consider specific investments in drying and storage operations borne by the farmers at either the farm or collection and storage level (i.e., cooperatives and collectors) [2]. In addition, there is a static approach to calculating profitability that does not consider the effects of this cropping system on the rotation cycle. This cropping system could gain interest among farmers if R\&D agents can provide evidence of the savings implied by a rotation cycle including wheat-pea intercropping [73,74].

\subsection{Difficulties in Collection and Storage}

Sorting is a key element that has not yet been perfected since the combine harvesters typically used to harvest wheat are used to harvest the wheat-pea mixture. Depending on the vertical organization of the value chain, storage is either provided by the farmer (in the case of sales to brokers or traders), by a cooperative to which the farm belongs, or by collection and storage providers. However, storage efficiency depends on the nature of the product stored since the wheat-pea mixture does not store as well as pure grains of wheat or pea. Moreover, there is a higher risk of mycotoxin development in silos with the wheat-pea mixture, resulting in the need to sort as quickly as possible.

Collection can also be complicated for cooperatives or collectors if production is dispersed over a large area with small volumes. High collection costs can quickly become an obstacle to the organization of the wheat-pea value chain, especially since cooperatives and collectors are accustomed to collection methods organized by the production basin "pool". If the volumes produced are sufficiently large in the same area, storage and collection are not constraints in themselves; however, the major issue for producers and cooperatives or collectors is sorting to separate peas from wheat.

This mixture is not marketable for human consumption; however, sorting may not be necessary if the mixture is to be used as animal feed $[2,74,80]$. While the technological solutions developed to 
date make it possible to sort peas for human consumption, they remain insufficient for wheat [81-83]. Additionally, there is a need for investment in adapting reception and storage infrastructures to manage both sorting and the flow of mixed or separated seeds. This specific investment is only feasible for economic operators in the value chain if production volumes are large enough to generate economies of a scale capable of amortizing investment costs [84]. At this stage, it is mainly the collectors or cooperatives that encounter logistical difficulties. Here, the technical constraints translate into the lack of a logistics base adapted to diversification for supply, storage management, and distribution $[85,86]$. Reception of the wheat-pea mixture requires the construction of a specific space (three silos: one for wheat, one for peas, and another for waste). Then, sorting requires an investment in establishing a new processing line. However, such sorting operations are systematically accompanied by a loss of quality attributed to an increased rate of split peas generated by the multiplication of logistical operations. The cost of this loss is estimated at $8 € /$ ton [82].

\subsection{Lack of Industrial Buyers}

The technology issue is less constraining further down the value chain as processors receive the wheat or peas separately. However, prerequisite sorting defines the quality of the wheat or peas available to processors and, thus, its compatibility with their processing technology [87]. The technological interrelationship that exists between conventional pure product value chains and the new value chain based on a wheat-pea mixture can contribute to the development and improvement of these processing technologies. This assumption is only valid if the upstream operators of the wheat-pea intercropping provide clear information on the intrinsic qualities of their new products, their prices of interest, and their accessibility in time and space. Intercropping products compete with conventional products for the supply of raw materials to processors. The latter only choose new sources of supply if they have comparative advantages over their usual source of supply. For them, there is also the constraint of making their innovative products recognized and accepted on the market [57]. In the absence of differentiation based on the quality of wheat-pea intercropping products, they enter into competition with conventional products, which puts them at a disadvantage on the supply market. In the conventional wheat value chain, wheat processors impose a major technological constraint on farmers (varietal choice), who must comply with very strict quality standards. For processors, flour quality is a key factor to be adjusted according to target markets that must be controlled. However, the quality of wheat produced from intercropping is not stable due to a lack of agronomic forecasts and logistical failures related to the storage and sorting of the mixture. For this reason, they prefer to work with conventional wheat whose varieties and characteristics are known and whose technological mastery will meet the different expectations of their customers (pastry chefs, bakers, etc.) [88].

\subsection{Uncompetitive Prices and Sale Channels}

Several works [89-93] have shown that the adoption of eco-friendly technology in agriculture is closely dependent on forms of market coordination. The products of wheat-pea intercropping can be marketed for human food or animal feed. In the highly branched and competitive human food market, the two products (wheat and peas) must be separated. Wheat, depending on its quality, will be directed through different channels with different transactions. Depending on the cooperatives or collectors, typical wheat is marketed through several contract arrangements in a highly concentrated downstream market [81]. These arrangements are outlined as follows:

- Short-term marketing contract without consideration of superior quality. The relationship is either established directly between the cooperative/collector and the manufacturer or via trading or brokers with the possibility of price reduction.

- Annual production contract where the price is given by a broker and the quality is compensated with a "bonus/malus" system. 
- Multi-year production contract without considering the superior quality and the possibility of a premium.

Operators in the food market use more generic criteria to assess wheat quality (i.e., moisture content, protein content, specific weight, and Hagberg index) [75,88,94,95]. In all contracting modes, price and quality are generally at the center of the arrangements between the different economic operators. Wheat market prices are highly volatile and influenced by international trade. Intercropping will not be of interest when wheat market prices are high; in this case, producers will choose the monoculture to maximize their yield and profit. However, wheat-pea intercropping gains interest when prices are relatively low; however, this is only the case if pea prices are attractive enough to compensate for the loss in profitability.

The human consumption market for dry peas is not very promising given the current situation, which is characterized by the increase in import customs duties in India (the world's leading consumer of dry peas) and the stagnation of demand in the local European market (approximately $12 \%$ of European production). Transactions are most often organized in physical markets, which hampers the potential to valorize peas from intercropping in the traditional value chain. Moreover, prices in this market are highly volatile, which does not offer stability for this value chain. This context can explain the over 20\% decrease in pea cultivated area between 2011 and 2012 in Europe [96].

In the highly concentrated animal feed market, wheat-pea mixture is a single product that can be used in the feed manufacturing industry or directly integrated by livestock farms with no technological treatment. In the latter scenario, the increasing constraint of feed safety creates an a priori need to pass through the industrial circuit to ensure that the raw material complies with health standards (i.e., the absence of mycotoxins and microorganisms) [97]. This leads not only to a dependence on the feed manufacturing industry but also to a considerable increase in costs (e.g., transport, storage, processing, and traceability), which reduces the competitive advantages of intercropped products as animal feed.

In the first scenario, wheat-pea mixtures compete with conventional feed industry inputs (mainly meals and grains) [98] for which historically established trade relationships are difficult to access. Even if pea production is historically devoted to animal feed, which absorbs $80 \%$ of production in Europe [96,99], its current use is only considered as a price adjustment variable on the animal feed market due to its intermediate nutritional profile (energy/protein). With the development of synthetic amino acids, peas have lost the historical attractiveness they had based on their lysine richness [100]. In addition, the low level of atomization of the feed industry makes small suppliers of raw materials (such as wheat-pea mixture) face oligopsony, especially since transactions are most often organized on the spot market. Some studies [81] describe the wheat-pea mixture as incompatible with the feed market. Notably, the current organization of the feed market does not provide reliable market opportunities for the wheat-pea mixture, which is reduced to small volumes dispersed over a large area. Therefore, suppliers of wheat-pea mixture for animal feed will need to contract to better secure their high valued "niche markets".

\subsection{Lack of Recognition for the Provision of Ecosystem Services}

Recognition of the ecosystem services provided by agriculture is an essential step toward their valuation and compensation by society [101-103]. Therefore, the evolution of the wheat-pea intercropping value chain must also be considered in its regulatory and public policy context, which remains partly unfavorable. Wheat-pea intercropping is not yet recognized by the Common Agricultural Policies (CAPs). While both cereal and protein crops benefit from coupled aid under the first pillar of the CAPs [104,105], no regulatory provisions have been adopted for intercropping. Therefore, the question of whether to declare an intercrop as a cereal or protein crop remains unanswered. Coupled subsidies are reserved for pure crops, which does not encourage farmers to adopt wheat-pea intercropping. Furthermore, since the wheat-pea mixture is not stable in plots, farmers risk penalties in the event of misdeclaration. The same is true for Agri-Environmental and Climate Measures (AECMs) 
premiums in the second pillar of the CAPs, which does not grant any environmental premium for this form of intercropping despite its benefits to ecosystems.

Furthermore, the European regulatory framework does not provide any mention of official quality linked to intercropping, crop diversification, and ecosystem services, which add value to products in the human or animal consumption market. This is necessary to promote the added value and transmission of incentives in the value chain.

\section{Levers for Developing Wheat-Pea Intercropping}

\subsection{Valorizing the Superior Quality of Wheat-Pea Intercropping Products}

The products of wheat-pea intercropping may be of interest in supplying new and innovative value chains for the production of plant protein material for human food and animal feed [99,106-110]. The high wheat content from the intercropping and the natural richness of protein from peas should be a real advantage to conquering this flourishing dietetic market. The emergence of new technologies for the extraction and incorporation of plant protein material and its various uses in manufacturing innovative products with high added-value [110-112] may provide incentives for downstream investment. The ecological quality of "environmental value" should also be promoted to consumers as a selling point to help consolidate the value chain [113-115]. Here, collective action supported by public policy is needed to get the ecosystem services provided by this value chain recognized.

Otherwise, the diversity of value chains for the products of wheat-pea intercropping must be considered as a source of wealth for the new "integrated" value chain insofar as the different actors of classical value chains use their network and fields of influence to promote the construction of the new value chain. These established relationships of trust and resource sharing can provide the foundation upon which the new integrated value chain can be built. Complementarities in terms of skills and resources among actors in traditional value chains can create synergistic relationships that can overcome the organizational and functional challenges of the new value chain.

Furthermore, the new integrated value chain can benefit from the favorable image conveyed by organic agriculture to consumers, manufacturers, and policymakers at the local, national, and European levels. This can attract the interest of large-scale distribution, whose involvement can contribute to the expansion of the consumer market for the products of wheat-pea intercropping $[26,116]$. This development path is interesting for peas, whose pure crop production is struggling to develop due to the difficulties of sanitary management and production. The nutritional characteristics of peas and their virtues in animal feed-like flax in the Bleu Blanc Cœur value chain $[117,118]$ —can be the subject of a qualitative differentiation in the market, which can be a source of opportunities for wheat-pea intercropping development.

\subsection{Eco-Labeling the Wheat-Pea Value Chain}

The wheat from intercropping has a superior physicochemical quality due to its higher protein content and the low presence of imperfections (i.e., vitreous aspect and speckle rate) [75]. The stockholders of the value chain must lead their marketing strategy toward differentiation, which will guarantee secure and competitive access to the already saturated cereals market. The possibility of wheat-pea production in organic farming gives the stakeholders a real opportunity to conquer this flourishing market, where supply remains very limited in the face of very solvent demand [119-124]. The environmental benefits offered by wheat-pea intercropping allow it to claim for an eco-labeling strategy, which could enable its stakeholders to display this quality guarantee as a marketing argument capable of boosting the value chain and satisfying consumer demand for agri-food products with high environmental value. The success of the Bleu Blanc Cœur value chain in highlighting the environmental and nutritional qualities linked to incorporating flax should provide a good practical example of constructing quality value chains capable of federating the different stakeholders (upstream and 
downstream actors, private R\&D centers, public organizations, and environmental and consumer associations [125]).

In the context of the European regulation on organic certification, which defines the qualifiers "organic" or "ecological" and the rules of organic agriculture product control and production, differentiation through quality requires collective and regulatory action. This requires the creation of environmental and nutritional quality specifications for value chains. For both human food and animal feed, this strategy of differentiation through quality must be coupled with varietal selection initiated at the beginning of the value chain. This process aims to develop crops with the physicochemical and taste qualities requested by processors and consumers. The aim is not only to secure market channels but also to create contract relationships for specific raw materials that can contribute to the sustainability of the value chain. The complementarity of organic farming certification and official quality sign approaches cannot be excluded, especially as products from intercropping systems are struggling to gain recognition among consumers [126].

\subsection{Establishing Local Supply Contracts}

The new wheat-pea value chain can also develop new coordination relationships that promote proximity between producers and consumers to take greater advantage of added value and reduce uncertainty for both producers (i.e., market opportunities) and consumers (i.e., quality and availability). The development of local value chains can highlight the ecological value of the product, avoid competition from conventional agriculture, and benefit from the comparative advantages of geographical proximity. In addition to their geographical proximity, stakeholders can establish multilateral contracts between the different levels of the new integrated value chain. For example, cooperatives can play an intermediary role between producers using wheat-pea intercropping and livestock farmers in the same territory. Some studies $[5,18,80,127]$ place the development of the wheat-pea intercropping value chain at the center of a territorial autonomy strategy in cereals and plant proteins.

\subsection{Involvement of Public Actors in Building the Wheat-Pea Value Chain}

In addition to funding R\&D, public agencies can play a catalytic role in developing the wheat-pea value chain. The ecosystem services provided by this cropping system are a common thread that can lead to the strong involvement of political authorities in constructing this value chain. The main political orientations of the CAPs are favorable to the involvement of public stakeholders in encouraging the adoption of practices with a positive ecological and societal footprint [128-131]. However, the challenge for the wheat-pea value chain involves grafting itself to this logic in order to be associated with the agroecological transition dynamics promoted by public stakeholders. Several partnerships or financing opportunities could be seized by promoters of the wheat-pea value chain. Financial and technical assistance is now available to stakeholders in diversification value chains, such as diversification contracts in the different regions in France as well as individual or collective diversification subsidies granted by various public authorities in France and Switzerland [132]. Furthermore, the diversification and development of local production are among the priorities of the European Agricultural Fund for Rural Development (EAFRD) programs in various European territories. This represents an opportunity for actors in the wheat-pea value chain to find financing sources and develop the positive image that their activity conveys to their territory. At this scale, other opportunities exist to construct diversification value chains that are more generic, such as the development of short chains supported by local authorities in different European countries.

\subsection{Involvement of RED Results in Advice}

The diverse and varied benefits of wheat-pea intercropping have been demonstrated by several works performed by R\&D organizations using a multi-disciplinary approach (e.g., agronomic, ecological, technical, economic, and social) $[2-7,10,11,14-18]$. This provides the value chain with a range of tools 
that can enable it to find suitable solutions to promote its integration into the agri-food market. The partnerships founded within the proposed framework including public and private stakeholders, as well as professional agricultural organizations, allow the value chain to start building its network, which carries positive economic externalities.

Difficulties in the value chain due to the lack of technical references can be explained also by the unconnected diversity of the different research done on intercropping. The diversity of the study contexts and approaches used can only benefit the development of more complete and universal reference frameworks that enable economic stakeholders to review and solve challenges standing in the way of adopting activities linked to the wheat-pea value chain. Such action, which is essential for the development of the integrated value chain, must be based on a local, regional, national, and European multidisciplinary approach drawn from the multiplicity of stakeholders and their interactions in the process of building new knowledge on the organization of a new integrated value chain $[22,133]$. This implies that a collection of results from work already carried out will be analyzed and combined to form a basis for future research. Notably, future research must address the priorities of economic stakeholders to avoid dealing with problems that are less relevant and help them to better adapt to changing market conditions by adopting innovative practices [134]. It also remains essential to define the role of each stakeholder in the design and implementation of technical reference systems for the value chain before their communication and extension (advice). The pooling of resources and coordination of R\&D actions are a necessary source of efficiency for the improved control of collective knowledge related to the development of the wheat-pea value chain. Building and transferring innovation knowledge requires the a priori ability to act differently, which implies that R\&D actors should establish a consulting approach based on partnership. This represents part of a long-term process that considers the specificity of each partner while promoting knowledge sharing and collective learning [135]. The success or failure of the first full-scale experiments carries a risk of misinterpretation of the results. Profitable production followed by failure (or failure from the first experiment) could quickly result in individuals turning against the adoption of the wheat-pea intercropping system. Both success and failure need to be rigorously evaluated by the stakeholders in diversification projects, where partnership in advisory work could provide a collective learning process favorable to the adoption of wheat-pea intercropping.

\subsection{Involvement of Business Partners in Support and Advice}

The changes brought about by implementing the intercropping system should be viewed by the stakeholders of conventional value chains as an opportunity to offer new products or services. For example, the need for sorting at collection and storage at the level of the cooperatives-collectors generates an additional investment cost compared to the conventional value chain. However, the need for advice and new inputs that are better suited to wheat-pea intercropping may allow them to develop a more specialized advising activity to partially offset the investment costs. Maintaining traditional coordination relationships and strengthening them as part of collective learning allows them to integrate new value-adding activities [46]. The success of work done by the Qualisol Cooperative and the feed processor Valorex in France can be cited as supporting farmers in innovation (technical, organizational, and commercial) for the development of wheat-lentil intercropping and successive flax production [136]. For stakeholders, trust and good reputations are necessary to create new market operating rules (e.g., the definition of quality standards) and acquire the knowledge necessary for the functioning of the value chain [4]. They can also rely on more formal relationships where contracting can provide them insurance for their transaction. The contracting of advisory and support activities for farmers allows their partners to be immune to uncertainty regarding the availability of raw materials and the product quality. This gives them incentives to undertake investments that can increase the productive performance of the value chain. 


\subsection{Consolidating Gains in Profitability}

Trials of this intercropping system in different areas of Europe show a positive balance in favor of its biomass weight productivity [137]. Savings made in terms of fertilization and phytosanitary treatment were also highlighted by different studies. Resistance to the instability of agroclimatic conditions that characterize the wheat-pea intercropping system gives it an economic advantage over pure crops by reducing the impact of climatic hazards on yield [55,60,85,138,139]. Its gross margin compared to that of pure crops shows a significant and more stable gain in annual profitability from one year to the next (i.e., less vulnerability to the volatility of raw material or finished product prices) [140]. Some studies [18] propose considering the profitability of this association according to specific objectives that result from a trade-off between weed management and grain yield. Wheat-pea intercropping can even improve the yield of the next crop in the rotation $[73,74,141]$. This finding serves as an argument to solicit the interest of farmers reluctant to adopt this farming practice. Policymakers and technical advisors should also use this argument as a key to unlock the division that exists around conventional value chains and prevent the development of this particular agroecological value chain. Notably, the economic profitability of adopting such eco-friendly practices represents a strong incentive for economic stakeholders to develop an integrated value chain [142-144].

\subsection{Specialized Training for Farmers}

Several studies have made a direct link between farmer training and the adoption of innovations [145-150]. The participation of farmers in specific training workshops to acquire the knowledge and skills needed to adopt new technologies accelerates their adoption [49]. The specialized training of farmers is considered a very useful extension and advisory approach for the adoption and dissemination of new agricultural practices, particularly for cereal-legume intercropping practices whose technical itinerary involving two crops remains difficult to drive [151]. Furthermore, it provides farmers with precise information on both the practices to be undertaken as well as their economic efficiency (e.g., yield and profitability compared to pure crops) and environmental efficiency (e.g., mineral nitrogen supply and use, phytosanitary product use, and resistance to diseases and climatic hazards).

\section{Conclusions}

Beyond highlighting the agroecological and economic benefits linked to crop diversification through wheat-pea intercropping, this review calls attention to the literature suggesting that the structuring of the value chain around wheat-pea mixture products faces a set of technical (i.e., varietal selection, phytosanitary problem control, production management itineraries, and collection and storage management), economic (i.e., cost, prices, market opportunities, and contractualization of exchange), and public policy (i.e., public support, recognition by the CAPs) obstacles that contribute to its slow adoption and dissemination in the European context. The dynamics of the production as well as the temporal, spatial, and logistical organization of pure crop value chains (wheat and pea) do not ensure the spontaneous integration of new intercropping products on the market. This can be explained by the fact that all economic stakeholders (i.e., producers, collectors, and processors), as well as technical and scientific support stakeholders, have oriented their strategies to meet the requirements of the conventional crop market.

However, the value chain stemming from the wheat-pea intercropping system presents areas for improvement (levers) to be exploited at all levels. The scientific and technical research conducted to date, the strong dynamics of certain branches of conventional value chains (i.e., niche markets for plant proteins and labeled products of high environmental value) and work aimed to raise awareness of the virtues of wheat-pea intercropping provide an impetus for its development. The new value chain must valorize its competitive advantages - particularly its ecosystem benefits and higher product quality - to assert its place in the market. It can seize multiple favorable economic opportunities to achieve the 
construction of a sustainable value chain. The results of this review identify priorities that must be addressed by all stakeholders in the wheat-pea value chain to better focus their efforts on significant issues and solutions to accelerate the adoption and dissemination of this agroecological system.

Author Contributions: Conceptualization, F.M. and M.F.; methodology, F.M.; formal analysis, F.M.; writing-review and editing, F.M. and M.F.; funding acquisition, M.F. All authors have read and agreed to the published version of the manuscript.

Funding: This research was funded by DiverIMPACTS (Diversification through rotation, Intercropping, Multiple cropping, Promoted with Actors and value chains towards Sustainability) funded by the European Union's Horizon 2020 research and innovation program under grant agreement No 727482.

Conflicts of Interest: The authors declare no conflict of interest. The funders had no role in the design of the study; in the collection, analyses, or interpretation of data; in the writing of the manuscript; or in the decision to publish the results.

\section{References}

1. Corre-Hellou, G.; Bedoussac, L.; Bousseau, D.; Chaigne, G.; Chataigner, C.; Celette, F.; Cohan, J.-P.; Coutard, J.-P.; Emile, J.C.; Floriot, M. Associations Céréale-Légumineuse Multi-Services. Innov. Agron. 2013, 30, 41-57.

2. Altieri, M.A. Ethnoscience and Biodiversity: Key Elements in the Design of Sustainable Pest Management Systems for Small Farmers in Developing Countries. Agric. Ecosyst. Environ. 1993, 46, 257-272. [CrossRef]

3. Malézieux, E.; Crozat, Y.; Dupraz, C.; Laurans, M.; Makowski, D.; Ozier-Lafontaine, H.; Rapidel, B.; De Tourdonnet, S.; Valantin-Morison, M. Mixing Plant Species in Cropping Systems: Concepts, Tools and Models: A Review. In Sustainable Agriculture; Springer: Berlin/Heidelberg, Germany, 2009; pp. 329-353.

4. Pierreux, J.; Delaplace, P.; Roisin, C.; Bodson, B. 10.1. L'intérêt de La Culture En Association de Froment et de Pois Protéagineux d'hiver Dans Un Objectif d'autonomie Protéique. Livre Blanc Céréales 2016, 10, 225-306.

5. Corre-Hellou, G. Acquisition de l'azote Dans Des Associations Pois-Orge (Pisum Sativum L.-Hordeum Vulgare L.) En Relation Avec Le Fonctionnement Du Peuplement. Ph.D. Thesis, Université d'Angers, Angers, France, 2005.

6. Corre-Hellou, G.; Brisson, N.; Launay, M.; Fustec, J.; Crozat, Y. Effect of Root Depth Penetration on Soil Nitrogen Competitive Interactions and Dry Matter Production in Pea-Barley Intercrops given Different Soil Nitrogen Supplies. Field Crops Res. 2007, 103, 76-85. [CrossRef]

7. Hauggaard-Nielsen, H.; Ambus, P.; Jensen, E.S. The Comparison of Nitrogen Use and Leaching in Sole Cropped versus Intercropped Pea and Barley. Nutr. Cycl. Agroecosyst. 2003, 65, 289-300. [CrossRef]

8. Justes, E.; Bedoussac, L.; Prieur, L. Est-Il Possible d'améliorer Le Rendement et La Teneur En Protéines Du Blé En Agriculture Biologique Au Moyen de Cultures Intermédiaires Ou de Cultures Associées? Innov. Agron. 2009, 4, 165-176.

9. Jensen, E.S.; Carlsson, G.; Hauggaard-Nielsen, H. Intercropping of Grain Legumes and Cereals Improves the Use of Soil N Resources and Reduces the Requirement for Synthetic Fertilizer N: A Global-Scale Analysis. Agron. Sustain. Dev. 2020, 40, 5. [CrossRef]

10. Rodriguez, C.; Carlsson, G.; Englund, J.-E.; Flöhr, A.; Pelzer, E.; Jeuffroy, M.-H.; Makowski, D.; Jensen, E.S. Grain Legume-Cereal Intercropping Enhances the Use of Soil-Derived and Biologically Fixed Nitrogen in Temperate Agroecosystems. A Meta-Analysis. Eur. J. Agron. 2020, 118, 126077. [CrossRef]

11. Naudin, C. Nutrition Azotée Des Associations Pois-Blé d'hiver (Pisum sativum L.-Triticum aestivum L.): Analyse, Modélisation et Propositions de Stratégies de Gestion. Ph.D. Thesis, Université d'Angers, Angers, France, 2009.

12. Naudin, C.; van der Werf, H.M.; Jeuffroy, M.-H.; Corre-Hellou, G. Life Cycle Assessment Appied to Pea-Wheat Intercrops: A New Method for Handling the Impacts of Co-Products. J. Clean. Prod. 2014, 73, 80-87. [CrossRef]

13. Piutti, S.; Schneller, C.; Guimont, H.-P.; Amiaud, B. Une Appoche Expérimentale Sur l'allongement Des Rotations et l'implantation de Bandes Enherbées En Grandes Cultures Pour Maximiser Les Services Rendus Par La Biodiversité Végétale et Microbienne. Innov. Agron. 2010, 8, 149-158.

14. Cong, W.-F.; Hoffland, E.; Li, L.; Six, J.; Sun, J.-H.; Bao, X.-G.; Zhang, F.-S.; Van Der Werf, W. Intercropping Enhances Soil Carbon and Nitrogen. Glob. Chang. Boil. 2015, 21, 1715-1726. [CrossRef] [PubMed] 
15. Hauggaard-Nielsen, H.; Jensen, E.S. Evaluating Pea and Barley Cultivars for Complementarity in Intercropping at Different Levels of Soil N Availability. Field Crops Res. 2001, 72, 185-196. [CrossRef]

16. Carlsson, G.; Bedoussac, L.; Cupina, B.; Djordjevic, V.; Gaudio, N.; Jensen, E.-S.; Jeuffroy, M.-H.; Journet, E.-P.; Justes, E.; Mikic, A. Does a Mixture of Pea Varieties with Different Leaf Morphology Improve Crop Performance? In Proceedings of the International Conference on Advances in Grain Legume Cultivation and Use, Novi Sad, Serbia, 27-28 September 2017.

17. Bourlet, C.; Vandewalle, A.; Jobic, G. Pulses Intercropped with Cereals to Secure the Pulse Production in Organic and Conventional Farming in Western France; INRAE: Budapest, Hungary, 2019.

18. De Vallavieille-Pope, C.; Belhaj Fraj, M.; Mille, B.; Meynard, J.-M. Les Associations de Variétés: Accroître La Biodiversité Pour Mieux Maîtriser Les Maladies. Les Doss. l'Environnement l'INRA 2006, 30, 101-109.

19. Fernández-Aparicio, M.; Amri, M.; Kharrat, M.; Rubiales, D. Intercropping Reduces Mycosphaerella Pinodes Severity and Delays Upward Progress on the Pea Plant. Crop Prot. 2010, 29, 744-750. [CrossRef]

20. Verret, V.; Gardarin, A.; Pelzer, E.; Médiène, S.; Makowski, D.; Valantin-Morison, M. Can Legume Companion Plants Control Weeds without Decreasing Crop Yield? A Meta-Analysis. Field Crops Res. 2017, 204, 158-168. [CrossRef]

21. Stomph, T.; Dordas, C.; Baranger, A.; de Rijk, J.; Dong, B.; Evers, J.; Gu, C.; Li, L.; Simon, J.; Jensen, E.S. Designing Intercrops for High Yield, Yield Stability and Efficient Use of Resources: Are There Principles? In Advances in Agronomy; Elsevier: Amsterdam, The Netherlands, 2020; Volume 160, pp. 1-50.

22. Fayaud, B.; Coste, F.; Corre-Hellou, G.; Gardarin, A.; Dürr, C. Modelling Early Growth under Different Sowing Conditions: A Tool to Predict Variations in Intercrop Early Stages. Eur. J. Agron. 2014, 52, 180-190. [CrossRef]

23. Borg, J.; Enjalbert, J.; Gauffreteau, A. Concevoir Des Associations Variétales de Blé Par l'idéotypage Participatif; INRA: Poitiers, France, 2015.

24. Ang, F.; Mortimer, S.M.; Areal, F.J.; Tiffin, R. On the Opportunity Cost of Crop Diversification. J. Agric. Econ. 2018, 69, 794-814. [CrossRef]

25. David, C.; Jeuffroy, M.-H.; Henning, J.; Meynard, J.-M. Yield Variation in Organic Winter Wheat: A Diagnostic Study in the Southeast of France. Agron. Sustain. Dev. 2005, 25, 213-223. [CrossRef]

26. Timaeus, J.; Weedon, O.; Frinchk, M.R. Experimental Screening of Pea and Wheat Genotypes for Mixture-Performance in a Baking-Wheat Cropping System; INRAE: Budapest, Hungary, 2019.

27. Heller, M.A.; Eisenberg, R.S. Can Patents Deter Innovation? The Anticommons in Biomedical Research. Science 1998, 280, 698-701. [CrossRef]

28. Bonneuil, C.; Demeulenaere, E.; Thomas, F.; Joly, P.B.; Allaire, G.; Goldringer, I. Innover Autrement? La Recherche Face à l'avènement d'un Nouveau Régime de Production et de Régulation Des Savoirs En Génétique Végétale. Doss. l'Environnement l'INRA 2007, 30, $29-53$.

29. Adham, K.; Siwar, C. Empirical Investigation of Government Green Procurement (GGP) Practices in Malaysia. OIDA Int. J. Sustain. Dev. 2012, 4, 77-88.

30. Klintong, N.; Vadhanasindhu, P.; Thawesaengskulthai, N. Artificial Intelligence and Successful Factors for Selecting Product Innovation Development. In Proceedings of the 2012 Third International Conference on Intelligent Systems Modelling and Simulation, Kota Kinabalu, Malaysia, 8-10 February 2012; pp. 397-402.

31. Ngah, A.H.; Zainuddin, Y.; Thurasamy, R. Barriers and Enablers in Adopting of Halal Warehousing. J. Islam. Market. 2015, 6, 354-376. [CrossRef]

32. Kusrini, E.; Qurtubi, Q.; Fathoni, N.H. Design Performance Measurement Model for Retail Services Using Halal Supply Chain Operation Reference (SCOR): A Case Study in a Retail in Indonesia. J. Adv. Manag. Sci. 2018, 6, 218-221. [CrossRef]

33. Trenbath, B.R. Intercropping for the Management of Pests and Diseases. Field Crops Res. 1993, 34, $381-405$. [CrossRef]

34. Ghaley, B.B.; Hauggaard-Nielsen, H.; Høgh-Jensen, H.; Jensen, E.S. Intercropping of Wheat and Pea as Influenced by Nitrogen Fertilization. Nutr. Cycl. Agroecosyst. 2005, 73, 201-212. [CrossRef]

35. Schoeny, A.; Jumel, S.; Rouault, F.; Lemarchand, E.; Tivoli, B. Effect and Underlying Mechanisms of Pea-Cereal Intercropping on the Epidemic Development of Ascochyta Blight. Eur. J. Plant Pathol. 2010, 126, 317-331. [CrossRef] 
36. Bedoussac, L.; Justes, E. The Efficiency of a Durum Wheat-Winter Pea Intercrop to Improve Yield and Wheat Grain Protein Concentration Depends on N Availability during Early Growth. Plant Soil 2010, 330, 19-35. [CrossRef]

37. Bedoussac, L.; Justes, E. A Comparison of Commonly Used Indices for Evaluating Species Interactions and Intercrop Efficiency: Application to Durum Wheat-Winter Pea Intercrops. Field Crops Res. 2011, 124, 25-36. [CrossRef]

38. Naudin, C.; Corre-Hellou, G.; Pineau, S.; Crozat, Y.; Jeuffroy, M.-H. The Effect of Various Dynamics of N Availability on Winter Pea-Wheat Intercrops: Crop Growth, N Partitioning and Symbiotic N2 Fixation. Field Crops Res. 2010, 119, 2-11. [CrossRef]

39. Lithourgidis, A.S.; Dordas, C.A.; Damalas, C.A.; Vlachostergios, D. Annual Intercrops: An Alternative Pathway for Sustainable Agriculture. Aust. J. Crop Sci. 2011, 5, 396.

40. Pelzer, E.; Bazot, M.; Makowski, D.; Corre-Hellou, G.; Naudin, C.; Al Rifaï, M.; Baranger, E.; Bedoussac, L.; Biarnès, V.; Boucheny, P. Pea-Wheat Intercrops in Low-Input Conditions Combine High Economic Performances and Low Environmental Impacts. Eur. J. Agron. 2012, 40, 39-53. [CrossRef]

41. Jumel, S.; Langrume, C.; Moussart, A.; Baranger, A. Assembling Rules for the Control of Ascochyta Blight in Winter Wheat/Pea Mixtures. In Symposium on Breeding for Diversification; Kassel University Press: Witzenhausen, Germany, 2018.

42. Malagoli, P.; Naudin, C.; Vrignon-Brenas, S.; Sester, M.; Jeuffroy, M.-H.; Corre-Hellou, G. Modelling Nitrogen and Light Sharing in Pea-Wheat Intercrops to Design Decision Rules for N Fertilisation According to Farmers' Expectations. Field Crops Res. 2020, 255, 107865. [CrossRef]

43. Paff, K.; Munz, S.; Vezy, R.; Gaudio, N.; Bedoussac, L.; Justes, E. Calibration and Evaluation of the STICS Intercrop Model for Two Cereal-legume Mixtures. In Proceedings of the ICROPM 2020-Crop Modelling for the future, Montpellier, France, 3-5 February 2020.

44. Vezy, R.; Munz, S.; Gaudio, N.; Launay, M.; Paff, K.; Lecharpentier, P.; Ripoche, D.; Justes, E. Improving the Intercropping Version of the STICS Model for Simulating Inter-Specific Competition. In XIIth Stics Users Seminar; CIRAD-INRAE: Montpellier, France, 2020; p. 26.

45. Hinsinger, P. Les Cultures Associées Céréale/Légumineuse: En Agriculture "Bas Intrants" Dans Le Sud de La France; Peuplements Complexes Performants en Agriculture à bas Intrants; Projet PerfCom: Montpellier, France, 2012; p. 27.

46. Martin, G.; Casagrande, M.; Blandier, M.L.; Bedoussac, L.; Boissinot, F.; Fontaine, L.; Médiène, S.; Valantin-Morison, M. Interplay: A Serious Game to Design and Evaluate the Introduction of Cereal-Legume Intercrops in Cropping Systems; INRAE: Budapest, Hungary, 2019.

47. Espinosa-Goded, M.; Barreiro-Hurlé, J.; Ruto, E. What Do Farmers Want from Agri-Environmental Scheme Design? A Choice Experiment Approach. J. Agric. Econ. 2010, 61, 259-273. [CrossRef]

48. Di Bene, C.; Baratella, V.; Trinchera, A.; Farina, R. Francaviglia. In Enhancing Diversification of Cropping Systems to Minimize Agri-Environmental Problems: Results of Stakeholders' Consultation in Italy; INRAE: Budapest, Hungary, 2019.

49. Meynard, J.M.; Charrier, F.; Fares, M.; Le Bail, M.; Magrini, M.B.; Charlier, A.; Messéan, A. Socio-technical lock-in hinders crop diversification in France. Agron. Sustain. Dev. 2018, 38, 54. [CrossRef]

50. Freins et Leviers à La Diversification Des Cultures. Etude Au Niveau Des Exploitations Agricoles et Des Filières. Synthèse Du Rapport d'étude. INRA pour le Ministère de l'Agriculture et de l'Ecologie. Available online: http://inra.dam.front.pad.brainsonic.com/ressources/afile/223799-6afe9-resource-etudediversificationdes-cultures-synthese.html (accessed on 15 April 2019).

51. Meynard, J.-M.; Charlier, A.; Charrier, F.; Fares, M.; Le Bail, M.; Magrini, M.-B.; Messéan, A. La Spécialisation à l'øeuvre. OCL 2013, 20, D402. [CrossRef]

52. Bybee-Finley, K.; Ryan, M.R. Advancing Intercropping Research and Practices in Industrialized Agricultural Landscapes. Agriculture 2018, 8, 80. [CrossRef]

53. Annicchiarico, P.; Collins, R.P.; De Ron, A.M.; Firmat, C.; Litrico, I.; Hauggaard-Nielsen, H. Do We Need Specific Breeding for Legume-Based Mixtures? In Advances in Agronomy; Elsevier: Amsterdam, The Netherlands, 2019; Volume 157, pp. 141-215. 
54. Guégan, T.; Klein, A.; Martin, J.; Houtin, H.; Pivato, B.; Lecomte, C.; Burstin, J. Determinism and Genetic Diversity of Pea Intercropping Ability in Peawheat Association. In Proceedings of the International Conference on Legume Genetics and Genomics (ICLGG 2019), Let's Harness the Potential of Legumes, Dijon, France, 13-17 May 2019.

55. Jamar, D.; Lecat, A.; Delanotte, L. Céréales et protéagineux d'hiver en agriculture biologique: Cultures pures et associations; résultats des essais 2010. In Livre Blanc «Céréales»; ULg Gembloux Agro-Bio Tech et CRA-W: Wallonie, Belgique, 2011.

56. Ronceux, A.; Favreliere, E.; Pernel, J.; Raviart, L. Cereal-Grain Legume Intercropping for Annual Weed Management: Feedback from Organic Farmers from" Hauts-de-France" Region. In Proceedings of the 23e Conférence du COLUMA. Journées Internationales sur la Lutte Contre les Mauvaises Herbes, Dijon, France, 6-8 December 2016; Association Française de Protection des Plantes (AFPP): Harrogate, UK, 2016; pp. 353-362.

57. Desclaux, D.; Chiffoleau, Y.; Nolot, J.M. Pluralité Des Agricultures Biologiques: Enjeux Pour La Construction Des Marchés, Le Choix Des Variétés et Les Schémas d'amélioration Des Plantes. Innov. Agron. 2009, 4, $297-306$.

58. Lefort, P.L.; Guy, P.; Buson, M.; Poisson, C. Aspects Biologiques de l'interaction Génotypes x Milieux. Recherche de Définitions Implications en Amélioration des Plantes Le Tocsin du Radiateur 1 1979, 79, 15-24.

59. Favrelière, E.T.; Ronceux, A. Caractérisation Des Associations de Cultures Protéagineux- Céréales. Mises En Euvre Des Agriculteurs de La Région Hauts de France. AgroTransfert 2016, 1, 1-23.

60. Justes, E.; Prieur, L.; Bedoussac, L.; Hemptinne, J.-L. Est-Il Possible d'améliorer Le Rendement et La Teneur En Protéines Du Blé Cultivé En Agriculture Biologique Au Moyen de Cultures Intermédiaires Ou de Cultures Associées? In Dinabio: Développement \& Innovation en Agriculture Biologique. Colloque National; INRA: Montpellier, France, 2008.

61. Ndzana, R.A.; Magro, A.; Bedoussac, L.; Justes, E.; Journet, E.-P.; Hemptinne, J.-L. Is There an Associational Resistance of Winter Pea-Durum Wheat Intercrops towards A Cyrthosiphon Pisum H Arris? J. Appl. Entomol. 2014, 138, 577-585. [CrossRef]

62. Lopes, T.; Bodson, B.; Francis, F. Associations of Wheat with Pea Can Reduce Aphid Infestations. Neotrop. Entomol. 2015, 44, 286-293. [CrossRef] [PubMed]

63. Vaquié, A. Intra-and Intercrop Diversification in Cereal Cropping and Effect on Pest Control. Ph.D. Thesis, AgroParisTech, Lyon, France, 2019.

64. Mansion-Vaquié, A.; Wezel, A.; Ferrer, A. Wheat Genotypic Diversity and Intercropping to Control Cereal Aphids. Agric. Ecosyst. Environ. 2019, 285, 106604. [CrossRef]

65. Mansion-Vaquié, A.; Ferrer, A.; Ramon-Portugal, F.; Wezel, A.; Magro, A. Intercropping Impacts the Host Location Behaviour and Population Growth of Aphids. Entomologia Experimentalis et Applicata 2020, 168, 41-52. [CrossRef]

66. Bedoussac, L. Analyse Du Fonctionnement Des Performances Des Associations Blé Dur-Pois D’hiver et Blé Dur-Féverole D’hiver Pour La Conception D'itinéraires Techniques Adaptés à Différents Objectifs de Production En Systèmes Bas-Intrants. Ph.D. Thesis, Université de Toulouse, Toulouse, France, 2009.

67. Ndzana Abanda, R.F.X. Régulation Des Bio-Agresseurs Dans Les Cultures Associées de Blé Dur et de Pois: Impact de La Diversité Végétale Sur La Démographie Des Pucerons Du Pois. Ph.D. Thesis, Université de Toulouse, Université Toulouse III-Paul Sabatier, Toulouse, France, 2012.

68. Jeuffroy, M.-H.; Biarnes, V.; Cohan, J.-P.; Corre-Hellou, G.; Gastal, F.; Jouffret, P.; Justes, E.; Landé, N.; Louarn, G.; Plantureux, S. Performances Agronomiques et Gestion Des Légumineuses Dans Les Systèmes de Productions Végétales; Edition Quae: Paris, France, 2015.

69. Miko, P.; Megyeri, M.; Cseresnys, I.; Takacs, T.; Vida, G. Examining Wheat-Pea Mixtures to Define Specific Selection Traits for Targeted Winter Wheat Breeding; INRAE: Budapest, Hungary, 2019.

70. Hellou, G.; Janus, F.; Mauline, M.; Baccar, R.; Lorin, M.; Poret, J.; Sorin, S.; Pelzer, E.; Médiène, S.; Jeuffroy, M.-H. Productivity and Pre-Crop Effects of Various Legume Species in Agricultural Conditions in Three French Regions. In Proceedings of the 15. European Society for Agronomy Congress (ESA), Geneva, Switzerland, 27-30 August 2018.

71. Šarūnaitè, L.; Deveikytė, I.; Kadžiulienè, Ž. Intercropping Spring Wheat with Grain Legume for Increased Production in an Organic Crop Rotation. Žemdirbyste = Agric. 2010, 97, 51-58.

72. Hauggaard-Nielsen, H.; Trydeman Knudsen, M.; Ravn Jørgensen, J.; Steen Jensen, E. Intercropping Wheat with Pea for Improved Wheat Baking Quality; Danish Consumer Council (Darcof): Odense, Denmark, 2006. 
73. Monti, M.; Pellicanò, A.; Santonoceto, C.; Preiti, G.; Pristeri, A. Yield Components and Nitrogen Use in Cereal-Pea Intercrops in Mediterranean Environment. Field Crops Res. 2016, 196, 379-388. [CrossRef]

74. Monti, M.; Pellicanò, A.; Pristeri, A.; Badagliacca, G.; Preiti, G.; Gelsomino, A. Cereal/Grain Legume Intercropping in Rotation with Durum Wheat in Crop/Livestock Production Systems for Mediterranean Farming System. Field Crops Res. 2019, 240, 23-33. [CrossRef]

75. Grčak, M.; Grčak, D.; Župunski, V.; Jevtić, R.; Lalošević, M.; Radosavac, A.; Kondić, D.; Živić, J.; Paunović, A.; Zećević, V. Effect of Cereals+ Pea Intercropping on Spike Index of Spring Wheat, Triticale, Oat and Pods Index of Pea. Acta Agric. Serbica 2019, 24, 167-180. [CrossRef]

76. Louarn, G.; Corre-Hellou, G.; Fustec, J.; Lô-Pelzer, E.; Julier, B.; Litrico, I.; Hinsinger, P.; Lecomte, C. Déterminants Écologiques et Physiologiques de La Productivité et de La Stabilité Des Associations Graminées-Légumineuses. Innov. Agron. 2010, 11, 79-99.

77. Banik, P. Evaluation of Wheat (Triticum Aestivum) and Legume Intercropping under 1:1 and 2:1 Row-Replacement Series System. J. Agron. Crop Sci. 1996, 176, 289-294. [CrossRef]

78. Subedi, K.D. Wheat Intercropped with Tori (Brassica Campestris Var. Toria) and Pea (Pisum Sativum) in the Subsistence Farming System of the Nepalese Hills. J. Agric. Sci. 1997, 128, 283-289. [CrossRef]

79. Prins, U.; de Wit, J. Intercropping Cereals and Grain Legumes: A Farmer's Perspective; Danish Consumer Council (Darcof): Odense, Denmark, 2006.

80. Pierreux, J. Autonomie Protéique Pour l'alimentation Du Porc: Les Perspectives Offertes Par La Culture En Association de Froment d'hiver et de Pois Protéagineux d'hiver; ULg Gembloux Agro-Bio Tech et CRA-W: Wallonie, Belgique, 2013.

81. Triboulet, P.; Magrini, M.-B.; Bedoussac, L. Coordination d'acteurs et Freins à l'adoption de Pratiques Innovantes Au Sein Des Filières Agro-Alimentaires: Réflexions à Partir de l'étude de La Filière Blé Dur. In 3. Journée D'études sur les Dynamiques Territoriales vers l'AB et L'écologisation des Systèmes Agri-Alimentaires-Ecodev Avignon; INRA: Avignon, France, 2013.

82. Bedoussac, L.; Triboulet, P.; Magrini, M.-B.; Rambault, G.; Foissy, D.; Corre-Hellou, G. Conséquences de l'introduction Des Cultures Associées Céréale-Légumineuse à Graines Dans Les Filières. Innov. Agron. 2013, 32, 199-212.

83. Verret, V.; Pelzer, E.; Bedoussac, L.; Jeuffroy, M.-H. Tracking On-Farm Innovative Practices to Support Crop Mixture Design: The Case of Annual Mixtures Including a Legume Crop. Eur. J. Agron. 2020, 115, 126018. [CrossRef]

84. Magrini, M.-B.; Béfort, N.; Nieddu, M. Technological Lock-In and Pathways for Crop Diversification in the Bio-Economy. In Agroecosystem Diversity; Elsevier: Amsterdam, The Netherlands, 2019; pp. 375-388.

85. Goulard, F.; Debril, T. Gérer et Préserver Des Ressources Naturelles; INRA: Toulouse, France, 2012.

86. Vézina, M.; Ben Selma, M.; Rousselière, D.; Audebrand, L.K. Diversification d'activités et Performance Des Coopératives Agricoles et Agro-Alimentaires: Propositions d'un Cadre Conceptuel; Sommet International des Coopératives: Montréal, QC, Canada, 2016.

87. Magrini, M.B.; Triboulet, P.; Bedoussac, L. Impacts Des Systèmes Agricoles Innovants Sur Les Filières Agro-Industrielles: Une Étude Sur Les Capacités Logistiques Des Coopératives Agricoles Pour Valoriser Les Cultures Associées Blé Dur-Légumineuse; The Center for Direct Scientific Communication: Schoelche, France, 2011.

88. Labarthe, P.; Coleno, F.; Fugeray-Scarbel, A.; Hannachi, M.; Lemarié, S. Freins et Leviers Socio-Économiques à La Diffusion Des Mélanges Variétaux Pour La Production de Blé: Une Comparaison Entre France et Danemark; Ministère de l'Agriculture et de la Pèche: Paris, France, 2018.

89. Fares, M.; Magrini, M.B.; Triboulet, P. Transition Agroécologique, Innovationet Effets de Verrouillage: Le Rôle de La Structure Organisationnelle Desfilières. Cah. Agric. 2012, 21, 34-45.

90. Bento, N.; Angelier, J.-P. La Transition Vers L'hydrogène Est-Elle Bloquée Par Un Verrouillage Technologique Au Profit Des Énergies Fossiles? LEPII-CNRS: Grenoble, France, 2009.

91. Lamine, C.; Meynard, J.M.; Bui, S.; Messean, A. Réductions d'intrants: Des Changements Techniques, et Après? Effets de Verrouillage et Voies d'évolution à l'échelle Du Système Agri-Alimentaire. Innov. Agron. 2010, 8, 121-134.

92. Duru, M.; Therond, O.; Fares, M. Designing Agroecological Transitions; A Review. Agron. Sustain. Dev. 2015, 35, 1237-1257. [CrossRef]

93. Hannachi, M.; Tichit, M. Does Biotechnological Innovation Require Organizational Innovation? Learning from the Cattle Breeding Industry in France. Anim. Front. 2016, 6, 80-85. [CrossRef] 
94. Abecassis, J. La Filière Blé: Entre Évolutions Technologiques et Sociétales; Entretiens du Pradel: Montpellier, France, 2011.

95. Intercéréales. La Filière Céréales Change de Paradigme! In Plan de Transformation de la Filière Céréales et Produits Céréalier; Intercéréales: Paris, France, 2017.

96. LEMOCI (Le Moniteur du Commerce International). Statistiques Des Oléagineux et Protéagineux Huiles et Protéines Végétales 2010-2011 de La Production à La Consommation France-Europe-Monde; Prolea Edition; LEMOCI: Paris, France, 2012.

97. Sebillotte, C. Les Microscénarios et Leur Construction. Un Exemple Sur Les Microscénarios de l'axe Stratégique «alimentation Animale» de La Prospective «Compétitivité Des Oléagineux Dans l'avenir». OCL 2002, 9, 352-361. [CrossRef]

98. Pousset, J. Associations de Céréales et de Légumineuses: Quelques Éléments Importants Pour Réussir. In GRAB de Basse-Normandie; Groupe de Recherche en Agriculture Biologique: Caen, France, 2004.

99. Watson, C.A.; Reckling, M.; Preissel, S.; Bachinger, J.; Bergkvist, G.; Kuhlman, T.; Lindström, K.; Nemecek, T.; Topp, C.F.; Vanhatalo, A. Grain Legume Production and Use in European Agricultural Systems. In Advances in Agronomy; Elsevier: Amsterdam, The Netherlands, 2017; Volume 144, pp. 235-303.

100. Charrier, F.; Magrini, M.-B.; Charlier, A.; Fares, M.; Le Bail, M.; Messéan, A.; Meynard, J.-M. Alimentation Animale et Organisation Des Filières: Une Comparaison Pois Protéagineux-Lin Oléagineux Pour Comprendre Les Facteurs Freinant Ou Favorisant Les Cultures de Diversification. OCL 2013, 20, D407. [CrossRef]

101. Mooney, H.A.; Ehrlich, P.R.; Daily, G.E. Ecosystem Services: A Fragmentary History. In Nature's Services: Societal Dependence on Natural Ecosystems, 1st ed.; Daily, G., Postel, S., Bawa, K.S., Kaufman, L., Eds.; Island Press: Washington, DC, USA, 1997.

102. White, A.; Scherr, S.; Khare, A. For Services Rendered: The Current Status and Future Potential of Markets for the Ecosystem Services Provided by Tropical Forests; International Tropical Timber Organization (ITTO): Kanagawa, Japan, 2004.

103. Gómez-Baggethun, E.; De Groot, R.; Lomas, P.L.; Montes, C. The History of Ecosystem Services in Economic Theory and Practice: From Early Notions to Markets and Payment Schemes. Ecol. Econ. 2010, 69, 1209-1218. [CrossRef]

104. Chatellier, V.; Guyomard, H. The Legislative Proposals of the CAP Reform (October 2011): First Analysis. INRA Sci. Soc. 2012, 2011, 1-11.

105. Maes, J.; Hauck, J.; Paracchini, M.L.; Ratamäki, O.; Hutchins, M.; Termansen, M.; Furman, E.; Pérez-Soba, M.; Braat, L.; Bidoglio, G. Mainstreaming Ecosystem Services into EU Policy. Curr. Opin. Environ. Sustain. 2013, 5, 128-134. [CrossRef]

106. Guéguen, J.; Walrand, S.; Bourgeois, O. Les Protéines Végétales: Contexte et Potentiels En Alimentation Humaine. Cahiers de Nutrition et de Diététique 2016, 51, 177-185. [CrossRef]

107. Estève-Saillard, M. Tendance de Marché En France Sur La Présence Des Protéines Végétales Dans Les Produits Alimentaires. OCL 2016, 23, D403. [CrossRef]

108. Henchion, M.; Hayes, M.; Mullen, A.M.; Fenelon, M.; Tiwari, B. Future Protein Supply and Demand: Strategies and Factors Influencing a Sustainable Equilibrium. Foods 2017, 6, 53. [CrossRef] [PubMed]

109. Gormley, R. Food Science and Technology Challenges for the 21st Century: Research to Progress Society: Outcomes from the 31st EFFoST International Conference 2017, Sitges, Spain. Trends Food Sci. Technol. 2018, 73, 89-94. [CrossRef]

110. Gonera, A.; Milford, A.B. The Plant Protein Trend in Norway-Market Overview and Future Perspectives. Nofima Rapport Serie 2018, 25, 1-27.

111. Petrusán, J.-I.; Rawel, H.; Huschek, G. Protein-Rich Vegetal Sources and Trends in Human Nutrition: A Review. Curr. Top. Pept. Protein Res. 2016, 17, 1-19.

112. Pojić, M.; Mišan, A.; Tiwari, B. Eco-Innovative Technologies for Extraction of Proteins for Human Consumption from Renewable Protein Sources of Plant Origin. Trends Food Sci. Technol. 2018, 75, 93-104. [CrossRef]

113. Munier-Jolain, N.; Carrouée, B. Quelle Place Pour Le Pois Dans Une Agriculture Respectueuse de l'environnement?' Argumentaire Agri-Environnemental. Cah. Agric. 2003, 12, 111-120.

114. Carrouée, B.; Schneider, A.; Flénet, F.; Jeuffroy, M.-H.; Nemecek, T. Introduction Du Pois Protéagineux Dans Des Rotations à Base de Céréales à Paille et Colza: Impacts Sur Les Performances Économiques et Environnementales. Innov. Agron. 2012, 25, 125-142.

115. Vincourt, P. New Ideotypes of Oil E Protein Crops; EDP Sciences: Les Ulis, France, 2018. 
116. Hassan, D.; Monier-Dilhan, S. National Brands and Store Brands: Competition through Public Quality Labels. Agribus. Int. J. 2006, 22, 21-30. [CrossRef]

117. Magrini, M.-B.; Duru, M. Trajectoire d'innovation Dans Les Systèmes Laitiers Français: Une Analyse Socio-Technique de La Démarche «Bleu-Blanc-Cøeur». Innovations 2015, 3, 187-210. [CrossRef]

118. Mourot, J.; De Tonnac, A. The Bleu Blanc Cøeur Path: Impacts on Animal Products and Human Health. OCL Oilseeds Fats Crops Lipids 2015, 22, D610. [CrossRef]

119. Kremen, A.; Greene, C.; Hanson, J. Organic Produce, Price Premiums, and Eco-Labeling in US Farmers' Markets; Economic Research Service, USDA: Washington, DC, USA, 2004.

120. Kremen, C.; Iles, A.; Bacon, C. Diversified Farming Systems: An Agroecological, Systems-Based Alternative to Modern Industrial Agriculture. Ecol. Soc. 2012, 17. [CrossRef]

121. Löschenberger, F. Stratégie de Sélection de Céréales Pour l'agriculture Biologique: L'exemple Du Blé Tendre. In Strategies for a Future without Cell Fusion Techniques in Varieties Applied in Organic Farming; ITAB: Paris, France, 2009.

122. Rossmanish, G. L'Association Kultursaat, Pour La Sélection Biodynamique de Légumes; ITAB: Paris, France, 2009.

123. Czarnezki, J.J. The Future of Food Eco-Labeling: Organic, Carbon Footprint, and Environmental Life-Cycle Analysis. Stan. Envtl. LJ 2011, 30, 3.

124. Delmas, M.A.; Grant, L.E. Eco-Labeling Strategies and Price-Premium: The Wine Industry Puzzle. Bus. Soc. 2014, 53, 6-44. [CrossRef]

125. Le Guillou, C.; Duflot, V. Oléoprotéagineux: Se Démarquer Par Une Démarche Qualité; EDP Sciences: Les Ulis, France, 2018.

126. Plénet, D.; Jeannequin, B.; Chauvin, J.-E. Diversité Des Agricultures Dans Les Filières Fruits, Légumes et Pomme de Terre. Innov. Agron. 2018, 68, 79-105.

127. Pierreux, J.; Delaplace, P.; Roisin, C.; Bodson, B. Perspectives Offertes Par La Culture En Association de Froment et de Pois Protéagineux d'hiver. Autonomie Protéique et Biométhanisation à la Ferme 2013, 1, $25-32$.

128. Plieninger, T.; Schleyer, C.; Schaich, H.; Ohnesorge, B.; Gerdes, H.; Hernández-Morcillo, M.; Bieling, C. Mainstreaming Ecosystem Services through Reformed European Agricultural Policies. Conserv. Lett. 2012, 5 , 281-288. [CrossRef]

129. Schomers, S.; Matzdorf, B. Payments for Ecosystem Services: A Review and Comparison of Developing and Industrialized Countries. Ecosyst. Serv. 2013, 6, 16-30. [CrossRef]

130. Hauck, J.; Schleyer, C.; Winkler, K.J.; Maes, J. Shades of Greening: Reviewing the Impact of the New EU Agricultural Policy on Ecosystem Services. Chang. Adapt. Socio-Ecol. Syst. 2014, 1, 51-62. [CrossRef]

131. Reed, M.S.; Moxey, A.; Prager, K.; Hanley, N.; Skates, J.; Bonn, A.; Evans, C.D.; Glenk, K.; Thomson, K. Improving the Link between Payments and the Provision of Ecosystem Services in Agri-Environment Schemes. Ecosyst. Serv. 2014, 9, 44-53. [CrossRef]

132. Soulié, M.; Bonifazi, M.; Quinio, M.; Ballot, R.; Jeuffroy, M.-H.; Pelzer, E. Co-Design and Assessment of Agronomical Scenarios for Reintroduction of Legumes into a French Territory; INRAE: Budapest, Hungary, 2019.

133. Gouache, D.; Penant, A.; Cadoux, S.; Schneider, A.; Biarnes, V.; Chambert, C.; Martin-Monjaret, C.; Flénet, F.; Vogrincic, C.; Muel, F. Implementing Applied Research and Development Approaches for Crop Diversification in French Arable Farming: A Strategic View from the French Oil and Protein Farmers' Applied Research Institute Terres Inovia; INRAE: Budapest, Hungary, 2019.

134. Chambers, R.; Thrupp, L.A. Farmer First: Farmer Innovation and Agricultural Research; Karthala Editions: Paris, France, 1994.

135. Aggeri, F.; Hatchuel, A. Ordres Socio-Économiques et Polarisation de La Recherche Dans l'agriculture: Pour Une Critique Des Rapports Science/Société. Sociologie du Travail 2003, 45, 113-133. [CrossRef]

136. Meynard, J.-M.; Jeuffroy, M.-H.; Le Bail, M.; Lefèvre, A.; Magrini, M.-B.; Michon, C. Designing Coupled Innovations for the Sustainability Transition of Agrifood Systems. Agric. Syst. 2017, 157, 330-339. [CrossRef]

137. Yu, Y.; Stomph, T.-J.; Makowski, D.; van der Werf, W. Temporal Niche Differentiation Increases the Land Equivalent Ratio of Annual Intercrops: A Meta-Analysis. Field Crops Res. 2015, 184, 133-144. [CrossRef]

138. Clerc, M.; Dierauer, H.; Böhler, D.; Kupferschmid, C. Essais Pratiques de Cultures Associées: Résultats de 2011. Rapport Sur Les Essais de Cultures Associées En 2011. FIBL Suisse 2011, 3, 1. 
139. Bedoussac, L.; Journet, E.-P.; Rouet, P.; Josse, C.; Ledoux, S.; Justes, E. Cultiver Du Blé (Dur Ou Tendre) En Association Avec Une Légumineuse à Graine: Un Moyen Efficace Pour Accroitre La Production et La Qualité Des Graines En Agriculture Biologique. In Journée Technique Grande Culture Biologique; ITAB/ARVALIS-Institut du Végétal, en Collaboration Avec l'INRA: Paris, France, 2011.

140. Bedoussac, L.; Journet, E.-P.; Hauggaard-Nielsen, H.; Naudin, C.; Corre-Hellou, G.; Jensen, E.S.; Prieur, L.; Justes, E. Ecological Principles Underlying the Increase of Productivity Achieved by Cereal-Grain Legume Intercrops in Organic Farming. A Review. Agron. Sustain. Dev. 2015, 35, 911-935. [CrossRef]

141. Corre-Hellou, G.; Dibet, A.; Aveline, A.; Crozat, Y. Le Pois Au Service Des Systèmes de Culture à Faibles Intrants: Quels Besoins Variétaux? Les Dossiers de L'Environnement de l'INRA 2006, 30, 111-116.

142. Guillain, R.; Legras, S.; Martin, E. Usages Agricoles Diversifiés Du Sol: Le Rôle Des Effets de Voisinage. Revue Économique 2017, 68, 409-433. [CrossRef]

143. Magrini, M.-B.; Anton, M.; Cholez, C.; Duc, G.; Hellou, G.; Jeuffroy, M.-H.; Meynard, J.-M.; Pelzer, É.; Voisin, A.-S.; Walrand, S. Transition Vers Des Systèmes Agricole et Agroalimentaire Durables: Quelle Place et Qualification Pour Les Légumineuses à Graines? Revue Française de Socio-Economie 2017, 1, 53-75. [CrossRef]

144. Magrini, M.-B.; Anton, M.; Cholez, C.; Corre-Hellou, G.; Duc, G.; Jeuffroy, M.-H.; Meynard, J.-M.; Pelzer, E.; Voisin, A.-S.; Walrand, S. Why Are Grain-Legumes Rarely Present in Cropping Systems despite Their Environmental and Nutritional Benefits? Analyzing Lock-in in the French Agrifood System. Ecol. Econ. 2016, 126, 152-162. [CrossRef]

145. Jamison, D.T.; Lau, L.J. Farmer Education and Farm Efficiency; Johns Hopkins University Press: Baltimore, MD, USA, 1982.

146. Morris, C.; Potter, C. Recruiting the New Conservationists: Farmers' Adoption of Agri-Environmental Schemes in the UK. J. Rural Stud. 1995, 11, 51-63. [CrossRef]

147. Feder, G.; Murgai, R.; Quizon, J. Sending Farmers Back to School: The Impact of Farmer Field Schools in Indonesia; The World Bank: Washington, DC, USA, 2003.

148. Mugisha, J.; Madsen, O.; Tumusiime, E.; Byekwaso, J. Performance of Farmers-Led Extension System in Agricultural Technology Transfer and Adoption. Uganda J. Agric. Sci. 2004, 9, 730-735.

149. Rezvanfar, A.; Samiee, A.; Faham, E. Analysis of Factors Affecting Adoption of Sustainable Soil Conservation Practices among Wheat Growers. World Appl. Sci. J. 2009, 6, 644-651.

150. Lemma, T.; Sehai, E.; Hoekstra, D. Status and Capacity of Farmer Training Centers (FTCs) in the Improving Productivity and Market Success (IPMS) Pilot Learning Woredas (PLWs); CGIAR: Addis Ababa, Ethiopia, 2011.

151. Labrada, R.; Officer, W. Farmer Training on Parasitic Weed Management. Prog. Farmer Train. Parasit. Weed Manag. 2008, 4, 1-5. 